\title{
PERTANGGUNGJAWABAN PEMERINTAH DESA SEBELUM DAN SESUDAH UNDANG- UNDANG NOMOR 6 TAHUN 2014 TENTANG DESA
}

\author{
Beverly Evangelista ${ }^{1}$, Zulhadi ${ }^{2}$ \\ STMIK Mataram ${ }^{1}$ \\ Universitas 45 Mataram $^{2}$ \\ beverlyevangelista48@gmail.com
}

\begin{abstract}
Abstrak - Terdapat perbedaan bentuk pertanggungjawaban pemerintah desa sebelum dan sesudah berlakunya Undang-undang Nomor 6 Tahun 2014 tengang Desa dimana sesudah berlakunya undang-undang tersebut pertanggungjawaban pemerintah desa lebih ketat baik kepada BPD maupun Bupati/Walikota dan masyarakat.

Adapaun permasalahan dalam tesis ini yakni : bagaimanakah pertanggungjawaban pemerintah desa sebelum dan sesudah Undang-Undang Nomor 6 tahun 2014 tentang desa ? dalam Hal apa saja pemerintah desa menyampaikan pertanggungjawaban kepada Pemerintah Kabupaten/Kota dan BPD ?

Jenis penelitian yang digunakan dalam tesis ini adalah penelitian hukum normatif dengan beberapa pendekatan yakni : Pendekatan perundang-undangan, Pendekatan Konseptual, Pendekatan Komparatif, Pendekatan Historis. Setelah berlakunya Undang-undang Nomor 22 tahun 1999 Tentang Pemerintah Daerah, Kepala Desa menyampaikan laporan dalam bentuk LPJ Kepala Desa. Dan setelah berlakunya Undang-undang Nomor 32 Tahun 2004 Tentang Pemerintah Daerah, Undang-undang Nomor 6 Tahun 2016 Tentang Desa, Kepala Desa menyampaikan laporan dalam bentuk LKPJ kepada BPD dan Bupati/Walikota serta masyarakat. Dalam hal pelaporan, ada dua jenis laporan pertanggungjawaban yang harus disampaikan oleh pemerintahan desa yakni laporan pelaksanaan Apebedes yang dilakukan pada setiap akhir tahun anggaran dan laporan pertanggungjawaban Kepala Desa pada masa akhir jabatan sebagai Kades.

Oleh sebab itu, penulis berkesimpulan bahwa pertanggungjawaban pemerintah desa haruslah disampaikan dalam LKPJ kepada BPD dan Bupati/Walikota serta masyarakat.
\end{abstract}

\section{Kata kunci : Pemerintah Desa, Pertanggungjawaban.}

Kata Kunci : Digital Signature, Ong-Shcnorr-Shamir, Subliminal Channel.

\section{LATAR BELAKANG}

Semenjak Indonesia merdeka sudah berganti banyak pengaturan tentang pemerintahan daerah maupun secara spesifik pengaturan tentang desa. Undang-undang akan selalu berubah mengikuti zaman. Hal ini dikarenakan tidak semua pasal dalam undang-undang pas atau sesuai untuk diterapkan disepanjang zaman. Demikian juga dengan undangundang tentang Pemerintahan Daerah khususnya berkaitan dengan desa.

Pergantian beberapa undang-undang tersebut berimplikasi pada pembangunan desa dalam segala bidang. Salah satunya berkaitan dengan kewenangan pemerintah Desa, termasuk didalamnya menyangkut mekanisme pelaporan dan pertanggungjawaban pemerintah desa.

Dalam sejarah pengaturan desa, telah ditetapkan beberapa pengaturan tentang desa, yaitu Undang-undang Nomor 22 tahun 1948 tentang pokok Pemerintahan Daerah, Undang-undang Nomor 1 tahun 1957 tentang pokok-pokok pemerintahan daerah, Undang-undang Nomor 18 tahun 1965 tentang pokok-pokok pemerintahan daerah, Undang-undang Nomor 19 tahun 1965 tentang Desa Praja sebagai bentuk peralihan untuk mempercepat terwujudnya daerah tingkat III di seluruh wilayah Republik Indonesia, Undang-undang Nomor 5 tahun 1974 tentang Pokok-pokok Pemerintahan Di Daerah, Undang-undang Nomor 22 tahun 1999 tentang Pemerintahan Daerah, dan terakhir dengan Undang-undang Nomor 32 tahun 2004 tentang pemerintahan daerah.

Undang-undang Nomor 32 tahun 2004 tentang Pemerintahan Daerah, didalamnya mengatur khusus berkaitan dengan pemerintah desa, badan permusyawaratan desa, lembaga-lembaga lain dan kerjasama desa yang di atur dalam pasal 200 sampai pasal 216. Ketentuan tersebut sebagai peraturan pelaksana diatur dalam Peraturan Pemerintah Republik Indonesia Nomor 72 Tahun 2005 tentang Desa.

Kemudian yang terbaru adalah Undangundang Nomor 6 tahun 2014 tentang Desa telah membawa perubahan mendasar bagi kedudukan dan relasi desa dengan daerah dan pemerintah baik dari aspek kewenangan, perencanaan pembangunan, keuangan dan demokrasi desa.

Salah satu bentuk tugas dan tanggungjawaban pemerintah desa sebagaimana yang diatur dalam Pasal 93 ayat 1 PP No 43 Tahun 2014 tentang Peraturan Pelaksana Undang-undang No 6 Tahun 2014 adalah melakukan perencanaan, 
pelaksanaan, penatausahaan, pelaporan, serta pertanggungjawaban terhadap dana desa.

Berdasarkan pada pasal 93 tersebut, dapat di lihat bahwa pertanggung jawaban temasuk dalam salah satu bagian dari Pengelolaan Keuangan Desa. Di dalam Pengelolaan Keuangan Desa tersebut pemegang Kekuasaan tertinggi yaitu Kepala Desa, sebagaimana di jelaskan lebih lanjut dalam pasal 75 Ayat 1 UU No 6 Tahun 2014 Jo pasal 93 ayat 2 PP No 43 Tahun 2014 yang menyatakan bahwa Kepala Desa Adalah pemegang kekuasaan pengelolaan keuangan Desa.

Hal ini menandakan bahwa Kepala Desa sebagai pemangku jabatan tertinggi dalam pemerintah Desa mempunyai kewenangan dalam pengelolaan keuangan desa. Artinya pertanggungjawaban dari pengelolaan keuangan desa di pegang oleh kepala desa, dan pada pelaksanaannya kepala desa dapat memberikan kuasa kepada perangkat desa dalam pengelolaan keuangan desa.

Berdasarkan data dari kementrian keuangan, jumlah alokasi dana desa (selanjutnya di sebut ADD) adalah 9,01 triliun rupiah. Siap tidak siap aparat desa harus mau untuk mengelolah dana tersebut dengan transparan dan akuntabel. Perangkat desa harus mempelajari cara penyusunan agenda pembangunan, selain itu aparat desa harus juga mempelajari sistem pembayaran, sistem akuntansi dan pelaporan sesuai dengan peraturan perundangundangan yang berlaku sebagai bentuk akuntabilitas terhadap publik.

Oleh sebab itu, sangat penting untuk diteliti terkait dengan proses pemerintah desa dalam menyusun dan menyampaikan pertanggungjwaban dana desa kepada masyarakat khususnya dalam hal ini kepada Bupati/walikota sebab dana desa merupakan aspek utama bagi pemerintah desa dalam membangun desanya.

\section{RUMUSAN MASALAH}

Berdasarkan uraian pada latar belakang di atas maka isu hukum yang diangkat dalam penelitian adalah: Bagaimanakah pertanggungjawaban pemerintah desa sebelum dan sesudah UndangUndang Nomor 6 tahun 2014 tentang desa ? Dalam Hal apa saja pemerintah desa menyampaikan pertanggungjawaban kepada Pemerintah Kabupaten/Kota dan BPD ?

\section{KAJIAN PUSTAKA}

Ada beberapa penlitian yang pernah dilakukan terkait dengan Pemerintah desa diantaranya :

a. Dinamika Kebijakan Pemerintahan Desa Di Indonesia Dari Masa Ke Masa (Studi Tahun
1979-2015) Oleh zainal dimana pada tulisannya tersebut membahas perkembangan pebijakan pemerintah desa yang diatur oleh beberapa perubahan peraturan perundang-undangan tentang desa. pada tulisan tersebut juga membahas bagimana pengaruh perubahan kewenangan kepala desa terhadap perkembangan kebijakan desa.

b. Pengelolaan Alokasi Dana Desa Dalam Mewujudkan Good Governance oleh Riska Apriliana yang menjelaskan terkait bagaimana seharusnya pengelolaan dan desa yang baik dan professional sehingga dapat membawa manfaat bagi masyarakat desa.

\section{METODE PENELITIAN}

Penelitian ini merupakan penelitian hukum normatif yaitu Penelitian hukum yang mengkaji kaidah-kaidah atau norma hukum yang berhubungan dengan masalah yang diteliti. Adapun pendekatan masalah yang digunakan diantaranya adalah : pendekatan perundang-undangan (statuta approach), pendekatan konseptual (conceptual approach) pendekatan komparatif (comparative approach) dan pendekatan historis (historical approach). Setelah sumber hukum dikumpulkan, selanjutnya akan di analisis bahan hukum tersebut dalam penelitian ini dengan menggunakan metode penafsiran hukum. Adapun penafsiran hukum yang digunakan yaitu penafsiran perbandingan hukum. Penafsiran perbandingan hukum adalah mengusahakan penyelesaian suatu isu hukum (legal issue) dengan membandingkan berbagai stelses hukum. Tentu yang dimaksud dalam penelitian ini yaitu membandingkan produk hukum yang berkaitan dengan pertanggungjawaban pemerintah desa sebelum dan sesudah undang-undang nomor 6 tahun 2014 tentang desa. Kemudian bahan hukum tersebut ditarik kesimpulan dengan menggunakan cara berpikir deduktif, yaitu dengan cara berpikir yang mendasar pada hal-hal yang bersifat umum kemudian ditarik kesimpulan secara khusus.

\section{PEMBAHASAN}

\section{Pertanggungjawaban Pemerintah Desa Sebelum Dan Sesudah Undang-Undang Nomor 6 Tahun 2014 Tentang Desa}

pemerintah Desa dalam menyampaikan laporannya menurut ketentuan Undang-Undang Nomor 5 Tahun 1979 Tentang Pemerintahan Desa adalah memberikan keterangan pertanggungjawabannya kepada Lembaga Musyawarah Desa atau disebut juga legislatif desa. Hal ensesni yang menjadi ciri dari ketentuan UU ini 
terkait dengan otonomi desa adalah hak untuk mengatur diri sendiri, ditiadakan. Desa sekedar satuan administratif dalam tatanan pemerintah. Dari pengertian ini jelas bahwa secara struktural dengan ditempatkannya desa sebagai organisasi pemerintahan langsung di bawah camat menunjukkan desa bersifat hierarkis sampai ke tingkat Pusat.

Pengaturan mengenai desa mengalami perubahan seiring dengan terbitnya Undang-Undang Nomor 22 Tahun 1999 tentang Pemerintahan Daerah. Undang-Undang ini secara nyata mengakui otonomi desa. Otonomi yang dimiliki oleh desa menurut Undang-Undang Nomor 22 Tahun 1999 tentang Pemerintahan Daerah adalah berdasarkan asal-usul dan adat istiadatnya bukan berdasarkan penyerahan wewenang dari Pemerintah.

Dalam perjalanan, UU Nomor 22 Tahun 1999 kemudin mengalami perubahan menjadi Undang-Undang Nomor 32 Tahun 2004 Tentang Pemerintahan Daerah. Ada beberapa Perubahan mendasar tampak dalam pemerintahan desa maupun dengan hubungannya dengan perangkat lainnya. Menurut Undang-Undang Nomor 32 Tahun 2004, Pemerintahan Desa terdiri dari Pemerintah Desa dan Badan Permusyawaratan Desa (BPD).

Dalam pengaturan UU No. 32 Tahun 2004 menegaskan bahwa Desa mempunyai kewajiban untuk memberikan laporan penyelenggaraan pemerintahan desa kepada Bupati/Walikota, memberikan laporan keterangan pertanggungjawaban kepada BPD, serta menginformasikan laporan penyelenggaraan pemerintahan desa kepada masyarakat sehingga Nampak dalam pengaturan UU ini pertanggungjawaban pemerintah desa lebih ketat dan lebih professional sehingga pengelolaan desa akan lebih transparan. Selain itu pula, beberapa hal yang diatur adalah terkait dengan pelayanan desa yang professional. Untuk meningkatkan pelayanan tersebut di dalam Undang-Undang Nomor 32 Tahun 2004 ditegaskan bahwa sekretaris desa akan diisi oleh Pegawai Negeri Sipil (PNS). Selain itu pula, Camat diberikan peranan yang tegas dalam kaitan dengan penyelenggaraan pemerintahan desa. Menurut ketentuan dalam Pasal 126 ayat (3) huruf a camat memiliki kewenangan untuk membina penyelenggaraan pemerintahan desa. Yang dimaksud dengan membina pada ketentuan ini adalah dalam bentuk fasilitasi pembuatan Peraturan Desa dan terwujudnya administrasi tata pemerintahan desa yang baik. Perbedaan lain yang mendasar antara Undang-Undang Nomor 22 dengan Undang-Undang Nomor 32 ialah perubahan Badan Perwakilan Desa menjadi badan Permusyawaratan
Desa, Badan Permusyawaratan Desa tidak mempunyai fungsi pengayoman adat.

Kemudian pada tahun 2007 pemerintah mengeluarkan Peraturan Menteri Dalam Negeri Nomor 35 Tahun 2007 Tentang Pedoman Umum Tata Cara Pelaporan Dan Pertanggungjawaban Penyelenggaraan Pemerintahan Desa. padap peraturan ini, dijelaskan secara rinci terkait dengan laporan pertanggungjawaban pemerintah Desa baik dalam masa pemerintahannya maupun dalam akhir masa jabatannya.

Setelah melalui proses panjang, pada tanggal 15 Januari 2014 lahirlah Undang-Undang Nomor 6 tahun 2014 tentang Desa. Dimana dalam undang-undang ini menggabungkan fungsi self government, sehingga diharapkan kesatuan masyarakat hukum adat yang selama ini merupakan bagian dari wilayah desa, ditata sedemikian rupa menjadi desa dan desa adat. Selain itu pula, mekanisme pertanggungjawaban kepala daerah juga diatur lebih rinci.

Salah satu laporan penting yang harus disampaikan oleh pemerintah desa adalah terkait dengan penggunaan dana Desa. Pelaporan keuangan meliputi segala aspek yang berkaitan dengan penyediaan dan penyampaian informasi keuangan terkait pelaksanaan Pembangunan Desa sesuai dengan kewenangan pemerintah desa. Laporan keuangan merupakan catatan informasi keuangan pemerintahan desa pada suatu periode akuntansi yang dapat digunakan untuk menggambarkan kinerja pemerintahan desa yang bersangkutan.

Pemerintah Desa harus menyusun laporan keuangan sebagaimana diatur dalam PP Nomor 43 Tahun 2014 tentang Peraturan Pelaksanaan Undang-Undang Nomor 6 Tahun 2014 Pasal 103 dan PP Nomor 47 Tahun 2015 tentang Perubahan atas Peraturan Pelaksanaan Undang-Undang Nomor 6 Tahun 2014.

Alokasi Dana Desa (ADD) merupakan dana yang dialokasikan oleh Pemerintah Kabupaten atau Kota untuk desa, yang bersumber dari bagian dana perimbangan keuangan pusat dan daerah yang diterima oleh Kabupaten atau Kota (PP No. 72 Tahun 2005 Pasal 1 ayat 11). Dana Desa yang bersumber dari APBN adalah wujud rekognisi Negara kepada desa. Bagian dari dana perimbangan pusat dan daerah yang diterima oleh Kabupaten atau Kota untuk desa ini paling sedikit $10 \%$ dari distribusi proporsional untuk setiap desa.

Alokasi Dana Desa (ADD) bertujuan untuk meningkatkan kesejahteraan dan pemerataan pembangunan desa melalui peningkatan pelayanan publik di desa, memajukan perekonomian desa, mengatasi kesenjangan pembangunan antar desa 
serta memperkuat masyarakat desa sebagai subjek dari pembangunan.

Dana Desa digunakan untuk membiayai penyelenggaraan pemerintahan, pembangunan, pemberdayaan masyarakat dan kemasyarakatan. Dana Desa harus diprioritaskan untuk pembangunan dan pemberdayaan masyarakat (PP No. 60 Tahun 2014 Pasal 19). Pembangunan desa adalah untuk meningkatkan kesejahteraan masyarakat desa dan kualitas hidup manusia serta penanggulangan kemiskinan.

Sedangkan untuk pemberdayaan masyarakat adalah untuk mendanai kegiatan yang bertujuan meningkatkan kapasitas warga atau masyarakat desa dalam pengembangan wirausaha, peningkatan pendapatan, serta perluasan skala ekonomi individu warga atau kelompok masyarakat dan desa.

Keuangan Desa dikelola berdasarkan praktik-praktik pemerintahan yang baik. Asas-asas Pengelolaan Keuangan Desa sebagaimana tertuang dalam Permendagri Nomor 113 Tahun 2014 yaitu transparan, akuntabel, partisipatif serta dilakukan dengan tertib dan disiplin anggaran.

Untuk bisa mendapatkan Alokasi Dana Desa, pemerintah desa harus menjalankan mekanisme dan Persyaratan Penyaluran Alokasi Dana Desa. Mekanisme yang pertama adalah pemerintah desa membuka Rekening desa yang nantinya Rekening Kas Desa tersebut akan menerima penyaluran Dana Desa dari pemerintah pusat (Permendagri No. 113 Tahun 2016).

Persyaratan penyaluran Dana Desa yaitu, pada Tahap I pemerintah desa harus menyerahkan laporan realisasi penggunaan Dana Desa tahun sebelumnya dan menunjukkan peraturan desa mengenai APBDesa. Kemudian untuk Tahap II, pemerintah desa harus menyerahkan laporan penggunaan Dana Desa Tahap I dan paling kurang $50 \%$ dari Dana Desa Tahap I telah digunakan.

Pada setiap tahap pencarian, tim pelaksana wajib menyusun Rencana Penggunaan Dana (RPD) dari Alokasi Dana Desa (ADD), dimana RPD Alokasi Dana Desa terdiri dari Rekapitulasi RPD dan Rincian RPD setiap kegiatan. Rekapitulasi RPD ini kemudian harus ditanda tangani oleh Kepala Desa dan Ketua BPD. Sedangkan Rincian RPD ditanda tangani oleh Ketua Pelaksana Teknis yang diketahui oleh Kepala Desa.

Pencairan Dana Desa ini dilakukan melalui Rekening Kas Desa. Pencairan Dana Desa dalam Rekening Kas Desa ditandatangani oleh Kepala Desa dan Bendahara Desa. Namun khusus bagi desa yang belum memiliki pelayanan perbankan di wilayahnya maka pengaturannya lebih lanjut akan ditetapkan oleh pemerintah Kabupaten/Kota.
Siklus pengelolaan berdasarkan UndangUndang Desa meliputi: 1) Penyiapan Rencana; 2) Musrenbang desa yang melibatkan pemerintah desa, BPD, dan kelompok masyarakat yang diawali dengan tingkat dusun hingga tingkat desa; 3) Penetapan Rencana, rencana disini merupakan pedoman APB Desa; 4) Penetapan APB Desa; 5) Pelaksanaan Pembangunan, melibatkan seluruh masyarakat secara swakelola; 6) Pertanggungjawaban, pemerintah desa wajib menyampaikan laporan dalam musyawarah pembangunan desa; 7) Pemanfaatan dan Pemeliharaan (UU No. 6 Tahun 2014).

Pengelolaan Dana Desa meliputi tiga kegiatan penting yaitu Perencanaan, Pelaksanaan, dan Pertanggungjawaban.

Perencanaan merupakan tahap awal dalam pengelolaan ADD. Kegiatan perencanaan ini dilakukan untuk menyusun kegiatan pelaksanaan ADD. Pertama, tiap dusun akan mengadakan Musyawarah Dusun (Musdus) untuk menampung usulan-usulan masyarakat mengenai program kerja apa saja yang akan dilakukan untuk tahun yang berkenaan (Permendagri No. 113 tahun 2014).

Disisi lain pemerintah desa membahas tentang perencanaan pembangunan desa yang meliputi RPJM Desa dan RKP Desa. Rencana Pembangunan Jangka Menengah Desa (RPJM Desa) untuk jangka waktu 6 tahun, sedangkan Rencana Kerja Pemerintah Desa (RKP Desa) untuk jangka waktu satu tahun. RKP Desa merupakan penjabaran dari RPJM Desa. Rancangan RKP Desa dilampiri Rencana Kegiatan dan Rencana Anggaran Biaya (RAB) yang telah diverifikasi.

Kemudian BPD menyelenggarakan Musrenbangdes yang diadakan untuk membahas dan menyepakati bersama mengenai rancangan RKP Desa dan juga untuk membahas tentang prioritas dan skala prioritas program kerja yang akan dilakukan pada tahun berkenaan sesuai dengan usulan masyarakat pada saat Musdus (Permendagri No. 113 Tahun 2014). RKP Desa menjadi dasar dalam penyusunan rancangan APB Desa (RAPB Desa). Rancangan peraturan desa tentang RKP Desa dibahas dan disepakati bersama oleh Kepala Desa dan BPD untuk ditetapkan menjadi peraturan desa tentang RKP Desa.

Musrenbangdes merupakan forum diskusi usulan rencana kegiatan pembangunan di tingkat desa yang berpedoman pada prinsip-prinsip Perencanaan Pembangunan Partisipasi Masyarakat Desa (P3MD). Prinsip ini mengharuskan keterlibatan masyarakat dalam pengambilan keputusan dan menentukan pembangunan yang akan dilaksanakan khususnya yang berlokasi di desa yang bersangkutan, sehingga benar-benar dapat 
merespon kebutuhan atau aspirasi yang berkembang.

Musrenbangdes ini adalah musyawarah antara Badan Permusyawaratan Desa (BPD), Pemerintah Desa (Pemdes), dan unsur masyarakat yang diselenggarakan oleh BPD untuk menyepakati hal-hal yang strategis. Yang dimaksud hal-hal yang strategis di desa seperti penataan desa, perencanaan desa, kerjasama desa, rencana investasi yang masuk ke desa, pembentukan BUM Desa, penambahan dan pelepasan aset desa, dan kejadian luar biasa. Musrenbangdes diselenggarakan secara partisipatif, demokratis, transparan dan akuntabel dengan berdasarkan kepada hak dan kewajiban masyarakat.

Salah satu indikator keberhasilan Musrenbangdes adalah keterlibatan masyarakat dalam Musrenbangdes. Semakin banyak dan semakin luas unsur masyarakat yang dilibatkan, maka legitimasi hasil Musrenbangdes menjadi semakin kuat dihadapan masyarakat. Karena itu, Musrenbangdes didesain untuk umum dan tidak bersifat rahasia. Setiap warga desa berhak untuk hadir sebagai peserta Musrenbangdes. Namun dalam pelaksanaannya, terkadang musrenbangdes hanyalah pertemuan formalitas antara tokoh masyarakat, pemerintah dan dewan.

Dalam Musrenbangdes akan dibahas pula mengenai pembentukan Tim Pengelola Kegiatan (TPK). TPK merupakan tim yang dibentuk oleh pemerintah desa yang selanjutnya ditetapkan oleh Kepala Desa dengan keputusan Kepala Desa. TPK terdiri dari dua unsur perangkat desa dan tiga unsur dari LKD (Lembaga Kemasyarakatan Desa). TPK memiliki tugas pokok yaitu menyusun Rencana Anggaran Biaya (RAB), menetapkan spesifikasi barang dan jasa, menyimpan dokumen pengadaan barang dan jasa, serta melaporkan semua kegiatan dan menyerahkan hasil pengadaan barang dan jasa kepada Kepala Desa disertai dengan Berita Acara Serah Terima Hasil Pekerjaan.

Kemudian setelah RKP Desa telah dibahas dan disepakati bersama, TPK menyampaikan usulan anggaran kegiatan kepada Sekretaris Desa berdasarkan RKP Desa yang telah ditetapkan. Kemudian Sekretaris Desa menyusun Rancangan APB Desa sesuai dengan RPJM Desa dan RKP Desa dan menyampaikan kepada Kepala Desa. Selanjutnya Kepala Desa menyampaikan kepada BPD untuk membahas dan menyepakati bersama. RAPB Desa tentang APB Desa disepakati bersama paling lambat bulan Oktober tahun berjalan antara Kepala Desa dan BPD (Permendagri No. 113 Tahun 2014).

RAPB Desa yang telah disepakati bersama, selanjutnya disampaikan oleh Kepala Desa kepada
Bupati/Walikota melalui Camat paling lambat tiga hari sejak disepakati untuk dievaluasi. Bupati/Walikota menetapkan hasil evaluasi RAPB Desa paling lama 20 hari kerja sejak diterimanya RAPB Desa. Jika hasil evaluasi menyatakan bahwa RAPB Desa tidak sesuai dengan kepentingan umum dan peraturan perundang-undangan yang lebih tinggi, maka Kepala Desa diberi waktu untuk menyempurnakan paling lama tujuh hari kerja sejak diterimanya hasil evaluasi. Peraturan desa tentang APB Desa ditetapkan paling lambat tanggal 31 Desember TA berjalan.

Dalam pelaksanaan kegiatan-kegiatan yang pembiayaanya bersumber dari ADD sepenuhnya dilaksanakan oleh Tim Pelaksana Desa (Pemerintah Desa). Untuk mendukung keterbukaan dan penyampaian informasi secara jelas kepada masyarakat, maka pada setiap pelaksanaan kegiatan fisik ADD wajib dilengkapi dengan papan informasi kegiatan yang dipasang di lokasi kegiatan. Papan tersebut sekurang-kurangnya memuat nama kegiatan, volume kegiatan, besaran anggaran dari ADD maupun swadaya masyarakat, dan waktu pelaksanaan kegiatan seperti yang telah disepakati dalam Musrenbangdes.

Untuk pelaksanaan pembangunan yang didanai oleh ADD harus melibatkan seluruh masyarakat atau lembaga kemasyarakatan, dan dilaksanakan secara swakelola dengan menggunakan sumber daya atau bahan baku lokal, dan diupayakan dengan lebih banyak menyerap tenaga kerja dari masyarakat desa setempat. Kemudian dalam pelaksanaannya, Bendahara Desa dapat menyimpan uang dalam kas desa pada jumlah tertentu untuk memenuhi kebutuhan operasional pemerintah desa. Batasan jumlah uang tunai yang disimpan dalam kas desa ditetapkan dengan peraturan Bupati/Walikota. Sedangkan dalam penatausahaannya, harus menggunakan sistem yang telah memanfaatkan Teknologi Informasi (TI) yaitu dengan menggunakan aplikasi yang telah dikembangkan oleh BPKP.

Penggunaan ADD dalam APB Desa digunakan paling banyak $30 \%$ untuk belanja Aparatur Desa dan Operasional Pemerintahan Desa (Pemerintah Desa dan BPD), dan paling banyak $70 \%$ untuk mendanai penyelenggaraan pemerintahan desa, pelaksanaan pembangunan desa, pembinaan kemasyarakatan desa, dan pemberdayaan masyarakat desa (Permendagri No. 113 Tahun 2014).

Laporan Pertanggungjawaban Realisasi Pelaksanaan APBDesa merupakan bagian tidak terpisahkan darilaporan penyelenggaraan Pemerintahan Desa. Laporan realisasi dan laporan pertanggungjawaban realisasi pelaksanaan 
APBDesa oleh pemerintah desa juga wajib diinformasikan kepada masyarakat secara tertulis dan dengan media informasi yang mudah diakses oleh masyarakat baik itu berupa papan pengumuman, radio komunitas, dan media informasi lainnya. laporan pertanggungjawaban realisasi APBDesa disampaikan kepada Bupati/Walikota melalui camat paling lambat 1 (satu) bulan setelah akhir tahun anggaran berkenaan.

Dalam hal laporan pertanggugjawaban pemerintah desa yang ditolak oleh BPD atas persetujuan sekurang-kurangnya $2 / 3$ dari jumlah anggota BPD yang hadir, termasuk pertanggungjawaban harus dilengkapi atau disempurnakan dalam jangka waktu paling lama 30 Hari disampaikan kembali kepada BPD.

Dalam Hal pertanggungjawaban kepala desa yang telah dilengkapi atau disempurnakan ditolak kedua kalinya, BPD dapat mengusulkan pemberhentian kepala desa kepada bupati dengan alasan-alasan yang dapat dipertanggung jawabkan. Sekretaris desa menyusun rancangan peraturan desa tentang pertanggungjawaban pelaksanaan APBDesa dan rancangan keputusan kepala desa tentang pertanggungjawaban kepala desa. Sekretaris desa menyampaikan kepada kepala desa untuk dibahas bersama BPD. Berdasarkan persetujuan kepala desa dengan BPD maka rancangan peraturan desa tentang pertanggungjawaban pelaksanaan APBDesa dapat ditetapkan menjadi peraturan desa. Jangka waktu penyampaian dilakukan paling lambat 1 (satu) bulan setelah tahun anggaran berakhir. Peraturan desa tentang pertanggungjawaban pelaksanaan APBDesa dan keputusan kepala desa tentang keterangan pertanggungjawaban kepala desa disampaikan kepada Bupati/Walikota melalui Camat. Waktu penyampaian paling lambat 7 hari kerja setelah peraturan desa ditetapkan.

\section{Bentuk Pertanggungjawaban Pemerintah Desa Kepada Pemerintah Kabupaten/Kota Dan BPD}

Pemerintahan Desa diselenggarakan oleh pemerintah desa, yakni Kepala Desa dan Perangkat Desa. Dua lembaga tersebut mempuyai kedudukan yang sama. Kewenangan Desa meliputi kewenangan di bidang penyelenggaraan Pemerintahan Desa, pelaksanaan Pembangunan Desa, pembinaan kemasyarakatan Desa, dan pemberdayaan masyarakat Desa berdasarkan prakarsa masyarakat, hak asal usul, dan adat istiadat Desa.

Pada pasal 21 UU Nomor 6 Tahun 2014 tentang Desa menyebutkan bahwa pelaksanaan kewenangan yang ditugaskan dan pelaksanaan kewenangan tugas lain dari Pemerintah, Pemerintah Daerah Provinsi, atau Pemerintah Daerah Kabupaten/Kota sebagaimana dimaksud dalam Pasal 19 huruf $\mathrm{c}$ dan huruf d diurus oleh Desa. Tetapi dalam kontruksi hukumnya ada kewenangan berasal dari penugasan dari Pemerintah, Pemerintah Daerah provinsi, dan Pemerintahan Kabupaten/ Kota. Mengacu dalam Undang-Undang Nomor 6 Tahun 2014 Pasal 22 yang menyatakan :

1. Penugasan dari Pemerintah dan/atau Pemerintah Daerah kepada Desa meliputi penyelenggaraan Pemerintahan Desa, pelaksanaan Pembangunan Desa, pembinaan kemasyarakatan Desa, dan pemberdayaan masyarakat Desa.

2. Penugasan sebagaimana dimaksud pada Ayat (1) disertai biaya.

Penugasan yang bisa datang dari Pemerintah, dan atau Pemerintah Daerah (bisa Pemerintahan Daerah Provinsi, bisa Pemerintah Daerah Kabupaten Kota) yakni; penyelenggaraan Pemerintahan Desa, pelaksanaan Pembangunan Desa, pembinaan kemasyarakatan Desa, dan pemberdayaan masyarakat Desa.

Berdasarkan hubungan tersebut, dalam ketentuan UU Nomor 6 Tahun 2014, maka pemerintah desa memiliki tanggungjawab untuk melaporkan hasil kinerjanya tidak hanya kepada Badan Permusyawaratan Desa, termasuk juga kepada Bupati/Walikota.

Mekanisme dan bentuk pertanggungjawaban Kepala Desa terbagi 2 (dua) yaitu:

a. Pertanggungjawaban Kepala Desa dalam melaksanakan APBDESA yang dilakukan pada setiap akhir tahun anggaran.

b. Pertanggungjawaban Kepala Desa pada masa akhir jabatan sebagai Kepala Desa.

Dalam PP Nomor 43 Tahun 2014 tentang Peraturan Pelaksanaan Undang-Undang Nomor 6 Tahun 2014 Pasal 103 dan PP Nomor 47 Tahun 2015 tentang Perubahan atas Peraturan Pelaksanaan Undang-Undang Nomor 6 Tahun 2014 pasal 104 telah diatur tentang pelaporan realisasi APB Desa sebagai bagian dari kegiatan Pelaporan dan Pertanggungjawaban Kepala Desa menyampaikan laporan realisasi pelaksanaan APB Desa kepada Bupati/Walikota setiap semester tahun berjalan.

Selain penyampaian laporan realisasi pelaksanaan APB Desa, Kepala Desa juga menyampaikan laporan pertanggungjawaban realisasi pelaksanaan APB Desa kepada Bupati/Walikota setiap akhir Tahun Anggaran yang telah ditetapkan dengan peraturan desa. Laporan tersebut merupakan bagian yang tidak terpisahkan dari laporan penyelenggaraan Pemerintahan Desa 
kepada Bupati/Walikota melalui Camat atau sebutan lain setiap akhir Tahun Anggaran.

Dalam melaksanakan tugas, kewenangan, hak, dan kewajibannya dalam pengelolaan keuangan Desa, Kepala Desa memiliki kewajiban untuk menyampaikan laporan. Laporan tersebut bersifat periodik semesteran dan tahunan, yang disampaikan ke Bupati/Walikota dan ada juga yang disampaikan ke BPD.

Laporan Realiasasi Pelaksanaan APB Desa disampaikan kepada Bupati/ Walikota melalui Camat yang terdiri dari:

1) Laporan Semester Pertama, disampaikan paling lambat pada akhir bulan Juli tahun berjalan;

2) Laporan Semester Akhir Tahun, disampaikan paling lambat pada akhir bulan Januari tahun berikutnya.

Laporan Realisasi Pelaksanaan APB Desa Semester Pertama menggambarkan realisasi pendapatan, belanja dan pembiayaan selama semester I dibandingkan dengan target dan anggarannya, sedangkan Laporan Realisasi Pelaksanaan APB Desa Semester Akhir Tahun menggambarkan Realisasi pendapatan, belanja dan pembiayaan sampai dengan akhir Tahun, jadi bersifat akumulasi hingga akhir tahun anggaran.

Laporan Pertanggungjawaban Realisasi Pelaksanaan APB Desa Setiap Akhir Tahun Anggaran disampaikan kepada Bupati/Walikota melalui camat setelah Pemerintah Desa dan BPD telah sepakat terhadap Laporan Pertanggungjawaban Realisasi Pelaksanaan APB Desa dalam bentuk Peraturan Desa (Perdes). Selanjutnya Perdes ini disampaikan kepada Bupati/Walikota sebagai bagian tidak terpisahkan dari Laporan Penyelenggaraan Pemerintahan Desa.

Laporan disampaikan paling lambat 1 (satu) bulan setelah Tahun Anggaran berkenaan. Laporan Pertanggungjawaban Realisasi Pelaksanaan APB Desa dilampiri:

a. Format Laporan Pertanggungjawaban Realisasi Pelaksanaan APB Desa Tahun Anggaran berkenaan;

b. Format Laporan Kekayaan Milik Desa per 31 Desember Tahun Anggaran berkenaan; dan

c. Format Laporan Program Pemerintah dan Pemerintah Daerah yang Masuk ke Desa.

Khusus untuk Peraturan Desa tentang Pertanggungjawaban Realisasi Pelaksanaan APB Desa tidak dilakukan evaluasi sebagaimana proses peraturan desa untuk penetapan APB Desa. Hal ini didasarkan ketentuan bahwa hanya 4 (empat) jenis Rancangan Peraturan Desa yang telah dibahas dan disepakati oleh Kepala Desa dan BPD yang dilakukan evaluasi oleh Bupati/Walikota melalui Camat yaitu tentang, APB Desa, Pungutan, Tata
Ruang, dan Organisasi Pemerintah Desa. Sesuai PP 43/2014 pasal 51, Laporan Pertanggungjawaban Realisasi Pelaksanaan APB Desa disampaikan kepada BPD secara tertulis paling lambat 3 (tiga) bulan setelah berakhirnya Tahun Anggaran.

Laporan Realisasi Penggunaan Dana Desa disampaikan kepada Bupati/Walikota setiap semester. Penyampaian laporan realisasi penggunaan Dana Desa dilakukan:

A. Untuk tahap I paling lambat minggu keempat bulan Juli Tahun Anggaran berjalan.

B. Untuk tahap II paling lambat minggu keempat bulan Januari Tahun Anggaran berikutnya.

Berdasarkan Laporan Dana Desa dari masing-masing desa yang ada di wilayah Kabupaten/Kota, selanjutnya Bupati/Walikota menyampaikan Laporan Realisasi Penyaluran dan Konsolidasi Penggunaan Dana Desa kepada Menteri Keuangan dengan tembusan menteri yang menangani desa, menteri teknis/pimpinan lembaga pemerintah non-kementerian terkait, dan Gubernur paling lambat minggu keempat bulan Maret Tahun Anggaran berikutnya.

Salah satu yang dapat dijadikan sebagai acuan dalam pengelolaan Dana Desa adalah Peraturan Menteri Desa, PDT dan Transmigrasi Nomor 21 Tahun 2015 tentang Prioritas Penggunaan Dana Desa Tahun 2016.

Sejalan dengan prinsip transparansi, akuntabel, dan partisipatif yang merupakan ciri dasar tata kelola pemerintahan yang baik (Good Governance), maka pertanggungjawaban tidak hanya disampaikan kepada pemerintah yang berwenang, tetapi juga harus disampaikan kepada masyarakat baik langsung maupun tidak langsung.

Secara langsung, pertanggungjawaban kepada masyarakat dapat dilakukan melalui Musyawarah Desa sebagai forum untuk membahas hal-hal strategis, yang dihadiri BPD dan unsur-unsur masyarakat lainnya. Selain itu, laporan pertanggungjawaban juga dapat disebarluaskan melalui berbagai sarana komunikasi dan informasi: papan Informasi Desa, web site resmi pemerintah Kabupaten atau bahkan desa.

Salah satu bentuk keterbukaan informasi kepada masyarakat, maka dalam pelaksanaan Pembangunan Desa yang dilaksanakan oleh Pemerintah Desa harus diinformasikan termasuk keuangannya kepada masyarakat. Hal itu sebagai wujud trasparansi yang merupakan asas dari penyelenggaraan pemerintahan dan pengelolaan keuangan desa.

Laporan Pertanggungjawaban Realisasi Pelaksanaan APB Desa sesuai ketentuan dan keterbukaan publik, diinformasikan kepada masyarakat secara tertulis melalui media informasi 
yang mudah diakses oleh masyarakat, antara lain papan pengumuman, radio komunitas, dan media informasi lainnya.

Dalam hal ini, Desa dapat mengembangkan Sistem Informasi Desa (SID) sistem ini merupakan kumpulan prosedur yang dilaksanakan oleh Pemerintah Daerah ke Desa, dan Pemerintah Desa dalam hal ini Kepala Desa kepada masyarakat desa terkait pemberian informasi yang menjadi dasar dalam pengambilan keputusan di Desa. Maupun untuk pihak yang terkait dengan Desa (Pemerintah Daerah, Pemerintah Pusat). ${ }^{1}$

Media yang digunakan dalam SID bisa berbagai macam, seperti: Papan Pengumuman atau Papan Informasi Desa, Surat Kabar Desa, Website Desa, Radio Komunitas, bahkan Televisi Desa, atau dapat pula melalui saluran informasi lainnya, baik yang berbentuk visual/video, audio, atau media tatap muka seperti Rapat Desa, Rapat Dusun/RT, dll. Terkait dengan website desa sesuai dengan prinsip rekognisi, maka desa dapat membuat domain sendiri sesuai dengan lampiran Permenkominfo Nomor 5 Tahun 2015 tentang nama domain desa.id untuk Pemerintahan Desa. Desa dapat menyesuaikan dengan peraturan yang berlaku. Namun yang perlu diperhatikan bukan sekedar penamaan domain, melainkan sistem yang mudah dijalankan oleh Desa. $^{2}$

Berdasarkan Peraturan Pemerintah Nomor 22 Tahun 2015 tentang Perubahan Atas Peraturan Pemerintah Nomor 60 Tahun 2014 tentang Dana Desa yang Bersumber dari Anggaran Pendapatan dan Belanja Negara, dalam hal Kepala Desa tidak atau terlambat menyampaikan laporan realisasi penggunaan Dana Desa, Bupati/Walikota dapat menunda

penyaluran Dana Desa sampai dengan disampaikannya laporan realisasi penggunaan Dana Desa.

Dalam pasal 27 Peraturan Pemerintah Nomor 22 Tahun 2015, disebutkan bahwa dalam hal terdapat SiLPA yakni Sisa Lebih Perhitungan Anggaran, yaitu selisih lebih realisasi penerimaan dan pengeluaran anggaran selama satu periode anggaran, lebih dari $30 \%$ pada akhir Tahun Anggaran sebelumnya, Bupati/Walikota memberikan

\footnotetext{
1 Suhardjo A.J, dkk. Geografi Perdesaan, Sebuah Antropologi; Yogyakarta; IdeAs Media, 2016. Hal. 43

2 Sumiati. (2015). Pengelolaan Alokasi Dana Desa Pada Desa Ngatabaru Kecamatan Sigi Biromaru Kabupaten Sigi. E-Jurnal Katalogis Vol. 3 No. 2 Februari 2015 hlm. 135
}

sanksi administratif Kepala Desa yang bersangkutan. Sanksi berupa penundaan penyaluran Dana Desa tahap I Tahun Anggaran berjalan sebesar Sisa Lebih Perhitungan Anggaran (SiLPA) Dana Desa. Dalam hal pada Tahun Anggaran berjalan masih terdapat Sisa Lebih Perhitungan Anggaran (SiLPA) Dana Desa lebih dari 30\%, Bupati/Walikota memberikan sanksi administratif kepada Desa yang bersangkutan. Sanksi berupa pemotongan Dana Desa Tahun Anggaran berikutnya sebesar Sisa Lebih Perhitungan Anggaran (SiLPA) Dana Desa tahun berjalan. Pemotongan penyaluran Dana Desa menjadi dasar Menteri melakukan pemotongan penyaluran Dana Desa untuk Kabupaten/Kota Tahun Anggaran berikutnya. Ketentuan mengenai pengenaan sanksi administratif diatur dengan peraturan Bupati/ Walikota.

\section{KESIMPULAN}

1. Setelah berlakunya Undang-Undang Nomor 22 tahun 1999 Tentang Pemerintah Daerah, Kepala Desa menyampaikan laporan dalam bentuk LPJ Kelapa Desa. Dan setelah berlakunya Undangundang Nomor 32 Tahun 2004 Tentang Pemerintah Daerah, Undang-undang Nomor 6 Tahun 2016 Tentang Desa, Kepala Desa menyampaikan laporan dalam bentuk LKPJ (Laporang Keterangan Pertanggungjawaban) Kepala Desa yang keduanya disampaikan kepada BPD dan Bupati/Walikota serta masyarakat.

2. Dalam hal pelaporan, ada dua jenis laporan pertanggungjawaban yang harus disampaikan oleh pemerintahan desa baik kepada masyarakat, BPD maupun Bupati walikota yakni laporan Pertanggungjawaban Kepala Desa dalam melaksanakan APBDESA yang dilakukan pada setiap akhir tahun anggaran dan laporan pertanggungjawaban Kepala Desa pada masa akhir jabatan sebagai Kades.

\section{Buku dan Artikel}

\section{DAFTAR PUSTAKA}

Diansari, Rani Eka. Analisis Implementasi Alokasi Dana Desa (ADD) Kasus Seluruh Desa di Kecamatan Kledung Kabupaten Temanggung Tahun 2013. Seminar Nasional Universitas PGRI Yogyakarta 2015.

Astuti, Titiek Puji dan Yulianto. Good Governance Pengelolaan Keuangan Desa Menyongsong Berlakunya Undang-Undang No. 6 Tahun 2014. 
Berkala Akuntansi dan Keuangan Indonesia, 2016.

Anak Agung Putu Wiwik Sugiantari, Pertanggungjawaban Alokasi Dana Desa Pelaga Terkait Program Pemberian Alokasi Dana Desa Kabupaten Badung. Fakultas Hukum Universitas Mahasaraswati : Denpasar.

Suhardjo A.J, dkk. Geografi Perdesaan, Sebuah Antropologi; Yogyakarta; IdeAs Media, 2016.

Sumiati. (2015). Pengelolaan Alokasi Dana Desa Pada Desa Ngatabaru Kecamatan Sigi Biromaru Kabupaten Sigi. E-Jurnal Katalogis Vol. 3 No. 2 Februari 2015.

\section{Peraturan Perundang-undangan}

Indonesia Undang-undang Nomor 5 tahun 1979 tentang Pemerintahan Desa.

Undang-undang Nomor 32 tahun 2004 tentang pemerintahan daerah. (Lembaran Negara Republik Indonesia Tahun 2004 Nomor 125)

Indonesia, Undang-undang Nomor 6 tahun 2014 tentang desa

Peraturan Pemerintah Republik Indonesia Nomor 72 Tahun 2005 tentang Desa.

Indonesia, Peraturan Menteri Dalam Negeri Republik Indonesia Nomor 113 Tahun 2014 Tentang Pengelolaan Keuangan Desa. (Berita Negara Republik Indonesia Tahun 2014 Nomor 2093).

Indonesia, Peraturan Menteri Dalam Negeri Republik Indonesia Nomor 46 Tahun 2016 Tentang Laporan Kepala Desa

\section{$\underline{\text { Internet }}$}

Siko dian sigit wiyanto, Agar Dana Desa Terkawal, www.google.com, diakses pada tanggal 22 Oktober 2018 